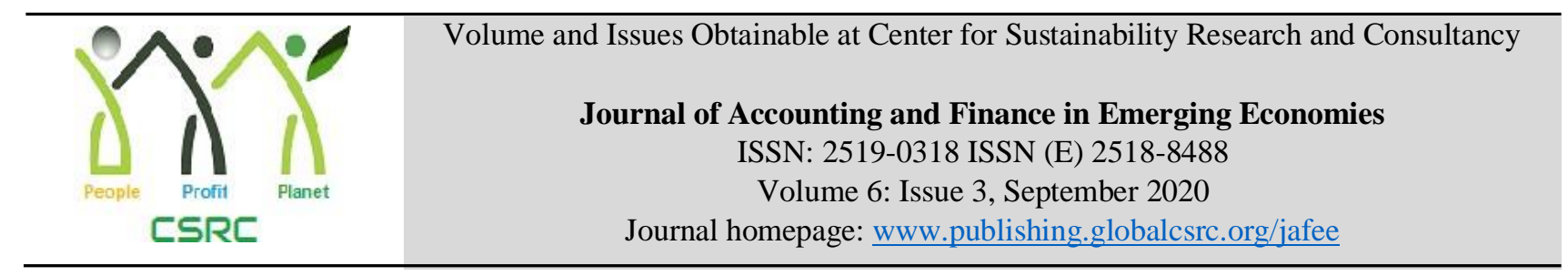

\title{
Green Banking Products: Challenges and Issues in Islamic and Traditional Banks of Pakistan
}

\author{
${ }^{1}$ Muhammad Hussain Qureshi, ${ }^{2}$ Talat Hussain \\ ${ }^{1} \mathrm{PhD}$ (Scholar)- Islamic Banking and Finance, School of Business and Economics/Institute of Islamic Banking, \\ Department of Banking and Finance, University of Management and Technology, Lahore, Pakistan, \\ hussainqureshi@hotmail.com
}

${ }^{2}$ School of Business and Economics /Institute of Islamic Banking, Department of Banking and Finance, University of Management and Technology, Lahore, Pakistan, talat.hussain@umt.edu.pk

\begin{tabular}{l}
\hline ARTICLE DETAILS \\
\hline History \\
Revised format: August 2020 \\
Available online: September \\
2020
\end{tabular}

\section{Keywords}

Green Products, Pakistan, Islamic Banks, Traditional Banks

\section{JEL Classification}

M40,M41

\section{ABSTRACT}

Purpose: The issuance of green banking guidelines in 2017 has opened the door of a new banking horizon for Islamic banks because the objective of Islamic banks, objective of Shariah, objective of Islamic economic system and objective of green banking are linked. Banking, especially Islamic banking based on products and one of the main components of green banking guidelines is the development of green banking products. Since green banking is in the infancy stage, therefore, the objective of the study is to explore the issues and challenges in green banking products in Islamic and traditional banks of Pakistan.

Methodology: Semi-Structured interview technique is utilized for data collection. The green operation managers and Shariah scholars of sample banks selected as interviewees. Interviews are conducted through telephonic recorded calls and email-interviewing. Total of 26 interviews are conducted.

Findings: The results indicate that lack of skills, knowledge, identification of the target market with the appropriate mode of financing and convincing the people are some main obstacles in green banking product formulation and implementation.

Implications: At one-point, green banking is an opportunity for Islamic banks to achieve Maqasid-e-Shariah on the other side, it may become an obstacle because it further limits the financing areas for Islamic banks. The situation needs serious attention from policymakers to act at earliest.

\section{OPEN ACCESS}

(C) 2020 The authors, under a Creative Commons Attribution-

NonCommercial 4.0

Corresponding author's email address: hussainqureshi@ hotmail.com

Recommended citation: Qureshi, M, H., \& Hussain, T. (2020). Green Banking Products: Challenges and Issues in Islamic and Traditional Banks of Pakistan. Journal of Accounting and Finance in Emerging Economies, 6(3), 703-712

\section{Introduction}

The objective of Islamic banks is different from traditional banks. Islamic banks being part of Islamic economic system work not only for the generation of profit rather welfare. The goals of Islamic economic systems based on Maqasid-e-Shariah "Objectives of Shariah" and the objective behind these objectives is welfare. In Islamic law, the welfare of all stakeholders is given much importance. The biggest problem in pursuance of the welfare of all stakeholders is the preservation of the environment, and the whole world is now heading towards this concept. green 
banking is one of the global actions for the protection of the environment. In response to global initiatives, State Bank of Pakistan (SBP) had issued a Green Banking Guideline in 2017, before this, there was no concept of green banking in Pakistan.

The objective of green banking is very close to the objectives of Shariah. The objective of green banking is the preservation of the environment that leads towards the preservation of Din, life, wealth, intellect and family. The same is the objective of Shariah. Therefore, objective of green banking, objective of Shariah and objective of Islamic banking are linked. Banking operations, especially Islamic banking based on products. Since one of the main components of green banking is the development of green banking products, hence implementation of green banking and development of green banking products are inevitable for banks, especially for Islamic banks.

As the green banking guidelines were issued in 2017, the phenomenon of green banking in relation to green products and Maqasid-e-Shariah is unaddressed. Previous studies e-g Hurayra (2015), Al-Amine (2015), Fisol, Ariffin, and binMat (2017), focus on explaining the importance of Maqasid-e-Shariah in Islamic finance and expenditures on zakat/sadaqat, and emphasized that Islamic banks must work to promote the social welfare of all (Zubaidah, 2019). In addition, previous studies on some aspects of green banking such as paperless banking operations and services are conducted in Bangladesh for example (Chowdhury \& Dey, 2016; Fayez, Mohammad, \& Md, 2013; Islam \& Das, 2013; Lalon, 2015) etc. After Bangladesh few studies are also conducted in China and India on managing green credit policy, such as (Aizawa \& Yang, 2010; Biswas, 2011; Sahoo \& Nayak, 2007; Zhang, Yang, \& Bi, 2011). Other regions such as Oman, Jordan, Singapore, and UAE also have one study each on green banking on reporting issues. But most of these studies based on the importance of green banking in traditional banks only. Moreover, this study is based on real-time data as opposed to above-mentioned studies. Against this backdrop, the present study investigates the issues and challenges in green banking products in Islamic and traditional banks of Pakistan to strengthen the level of Maqasid-e-Shariah and welfare of all stakeholders in whole banking structure of Islamic banks and fulfil the GAP. Therefore, the main objective of the study is "To know the issues and challenges in green product development in Islamic and traditional banks of Pakistan".

\subsection{Significance}

green banking is very much close to Islamic objectives of Shariah, (Maqasid-e-Shariah). Therefore, the identification of issues and challenges in green banking product may help in achieving the objectives of Shariah at the bank level as well as at the industry level. Therefore, by identifying the issues and challenges in green product development, the study may provide firsthand knowledge to academic and corporate readers on current banking practices on green banking products in Islamic and traditional banks of Pakistan. The difficulties identified may describe the difficulties in achieving Maqasid-e-Shariah in Islamic banks.

For regulatory authorities, the study may help in ascertaining the usefulness of green banking guidelines in term of green product development because this study is based on real-time data. This study may help SBP in identifying the outcomes, challenges and recommendations for developing green banking products and for the establishment of green banking framework, that may further become helpful in developing a regulatory framework on green banking ${ }^{1}$. It is also interesting to conduct this study on Islamic banks because, in the guidelines, no specific instructions are quoted for Islamic banks to keep intended their different business model and product structures. Therefore, it will be an interesting study, that how Islamic banks are developing green products and what are the outcomes, and what obstacles they are facing in the development process and what are the solutions for these challenges. Ultimately this may help in the formulation of green product development framework for Islamic banks based on Maqasid-e-Shariah. The following model depicts the implication of this study in the shape of a new banking horizon for Islamic banks.

\footnotetext{
${ }^{1}$ A per GBG the next step is the development of green banking regulations.
} 
Green products as a tool for acheievement of Maqasid-eSharaih

- Preservation of Din, Life, Intellect, Family, Wealth
Islamic Banking (1)

-Prohibitin of Riba, Gharar, Mayser
New Banking Horizon, acheieving the objectives of Islamic economic system

- Blending Green Banking and Islamic Banking

Figure 1 New Banking Horizon (Blending green banking with Islamic Banking)

For managers, this study may help in identifying the difficulties and the aspects that affect the application of green product development and the banking elements that are affected by the development of green products in Islamic and traditional banks of Pakistan. Further, this study may provide a solution to the challenges faced by traditional and Islamic banks while developing green products.

The study may also help in achieving sustainable development goals and enhancing the confidence of customers in Islamic banking. Further, the study may help in exploring the untapped financing areas. Furthermore, this may help in developing green banking products for Islamic banks, such as green Ijarah, green Murabaha and green Musharakah etc.

\section{Literature}

This section provides the details of studies conducted on green banking in different regions of the world. The previous studies are also presented in chronological order to gain an historical view of the previous studies.

\subsection{Green Banking in Bangladesh}

In earlier studies on green banking in Bangladesh, Fayez, Mohammad, and Md (2013) found that policy guideline, demand for loans, stakeholders' pressure, environmental, economic and legal factors affect the implementation of the green banking guidelines in commercial banks of Bangladesh. Furthermore, Millat, Chowdhury, and Singha (2013) ${ }^{2}$ claimed that banks show positive attitude towards implementation of green banking guidelines due to economic factors and to fulfil moral obligations. In the same year Md Masukujjaman and Aktar (2013) claimed that banks have a lot to do in this area, such as formation of climate risk funds, environmental due diligence and investments in renewable energy projects. In another study Islam and Das (2013) spotlighted the practices of green banking in Bangladesh. The study focused on mobile and online banking, green financing, the guideline on green banking and green banking units. The study suggests that due to globalization, practices of green banking are becoming inevitable. Later, Lalon (2015) found that there are some opportunities for banks adopting green banking practices such as improving brand image and technical assistance from central bank. In the same year, Mohammad Masukujjaman, Siwar, Mahmud, and Alam (2015) reveal that bankers see green bankers as a socially responsible banker. green banking helps in protecting environment, albeit green banking is a high cost venture. The study further reveals the compatibility between green banking and Islamic banking such as saving resources, cleanliness, and social accountability. In the next year, Chowdhury and Dey (2016) argued that major initiatives towards green banking by central bank of Bangladesh are formulation of polices, strategies and allocation of budgets to banks for green initiatives. They also claimed that the utilization of these budgets is increasing but at a slower pace. However, the barriers can be removed through special incentive packages for green investments. In the same year, Hossain, Bir, Tarique, and Momen (2016) imply that even the absence of reporting guideline, banks in Bangladesh are reporting the green banking practices in their yearly reports. But the lack of standardized reporting guideline is one of the obstacles in consistency of reporting. However, by considering the central bank as strong stakeholder, banks are following the instructions of central bank for green initiatives. Then Julia, Rahman, and Kassim (2016) found that all the aspects of

\footnotetext{
${ }^{2}$ This study was conducted by central bank of Bangladesh and based on the information provided by the banks on green activities in response to the guidelines announced by the central bank of Bangladesh.
} 
green banking, such as governance, environmental and credit risk management, funds for climate risk management, awareness, disclosure, training and green financing, are very much in line with the objectives of Shariah. They claimed that green banking Guidelines issued by Bangladesh Bank may easier for Islamic banks to implement as these may help in fulfilling the objectives of Shariah such as preservation of wealth life and family. Similar to Islam and Das (2013) , Hoshen, Hasan, Hossain, Al Mamun, and Mannan (2017) found that privately owned commercial banks in Bangladesh are contributing more funds in green projects, and tendency to finance green projects is also increasing in these banks. However, to accelerate the goals of sustainable development a revision is required in green banking policy. In the same year, Sekreter (2017) found that green finance and Islamic finance are expending in two different geographical regions. The study found that though Murabaha is the major product of Islamic banks, Sukuk and Musharakah based products may also become major tools for Islamic banks in increasing green financing. Afterward, Alam, Julker, Rashedul, and Khadiza (2017) examined different green banking models. In addition to review of literature the study also utilized the in-depth interview technique, to obtain some personal perspective of banking leaders and to explore the opportunities and hurdles in initiating green banking activities in banks. The study found that green banking if implemented in true sense may become an effective tool for controlling polluting businesses. Most recently, Chen, Hossen, Muzafary, and Begum (2018) found that banks in Bangladesh are performing well on sustainable development goals and are acting according to the guideline of Bangladesh Bank. The study found that banks mostly report those activities which are good in nature, this type of green banking helps in attracting customers, regulators and public. Furthermore, adoption of green activities enhances the legality to the businesses. Similarly, Ghosh, Ghosh, and Chowdhury (2018) claims that mandatory, rather than voluntary implementation of green practices may create a difference.

\subsection{Green Banking in India}

In initial studies on green banking Sahoo and Nayak (2007) claimed that, being the major stakeholder of industrial sector, banks face difficulties in managing credit and liability risk, quality of assets and return rate in long run. Therefore, to tackle these issues, it is important for banks to be proactive and play their role in going green. Banks should include the ecological and environmental aspects in their lending principles. This will force industries to take compulsory actions for environment management, application of appropriate technologies and management system. The study also found the importance of green banking and highlights some international practices on green and sustainable goals. The study also claimed that the level of green banking in Indian banks is not very encouraging, therefore, needs a policy guideline for effective implementation. Later, Thombre (2011) claims that banks' external activities have huge impact on environment, though it is tough to measure the impact. Therefore, promotion of environmental friendly investments and cautious lending responsibilities rest on banks (Sahoo \& Nayak, 2007). Banks should proactively play their role in incorporating environmental aspects in their lending procedures (Hayder, 2012). The focus from profit, profit and profit is therefore gradually shifting to people, planet and profit (Verma, 2012). Furthermore, Biswas (2011) found that going green is a must for banks, though the approach in banks is not very proactive. Similar to Sahoo and Nayak (2007) emphasized that ecological aspects and environmental preservation should be a part of banks' lending process. This will encourage industries to utilize suitable technology and management system. After two years Bhardwaj and Malhotra (2013) argue that concept of green banking is equally beneficial to economy, industry and banks. Adoption of green banking not only helps in greening of industry but also increases the worth of assets of banks. They further claimed that adoption of green banking influences the performance of companies. Next, Nath, Nayak, and Goel (2014) highlights some challenges of adopting green banking such as higher operational cost and lack of specialization, talent and expertise. In addition, banks are also confronting to reputational risk due to non-compliance with green guidelines. The study also highlights some reasons behind global warming through banking sector, and attributes this to late sitting in banks with well-lighted offices, more computers and electricity usage. In recent studies, Deka (2015) highlighted three issues, first the green banking practices, secondly, the impact of green activities on sustainability, and thirdly, customers awareness regarding green activities in Assam. The study reveals a direct impact of green banking on sustainability due to being easy, convenient and cost effective for customers. However, there is a lack of literacy regarding green banking in customers. Most recently, Shetty and Unnikrishnan (2017) claimed that green baking is pursuing in two broader dimensions. The focus of US Banks is on financing green projects, while focus of banks in India is on green banking operations. However, banks in India may also boost green banking by focusing on green and clean projects. 


\subsection{Green Banking in China}

In preliminary studies on green policy, Aizawa and Yang (2010) claimed that success of implementation of green credit policy depends on collection and dissemination of environmental data, technical assistance, and financial incentive for banks. Continuation in successful implementation will provide china with experiences and confidence to confront new challenges such as social and environmental conduct of its overseas businesses. In next year another study was conducted by Zhang, Yang, and Bi (2011), the study found that level of implementation of green credit policy at national level is not very encouraging. Wide range of highly polluting and energy consuming industries, unclear policy details, vague standers of implementation and absence of environment related information are the main obstacles in the implementation of the policy. After two years Bal, Faure, and Liu (2014) identify some important facts related to green credit in China. First, only a few small-scale banks are applying internationally accepted green principles. Secondly, there is a lacking in some areas such as establishment of inclusive risk management system, transparent disclosure of environment related information, monitoring and capacity building. In recent studies on green lending policies in china (Cui, Geobey, Weber, \& Lin, 2018) found that green financing is gaining popularity in china after the issuance of Green Credit Policy, by conducting a panel data study on twenty four chines banks, the study explained the relative riskiness of green loans as compared to non-green loans. The data set was collected for five-years, regression technique with two-stage least square is applied to test the relationship. The study found that inclusion of more green loans in loan portfolio reduces the amount of non-performing loans. The study indicates that implementation of green credit policy positively affects the environmental and financial performance of chines banks. The study also provides some suggestions for improving the green financing performance of chines banks. First, green lending policy should be considered as an initial step and not an end. Secondly, government should play its role by providing incentives to banks for green lending. Third, role of NGOs should be encouraged. Fourth, close monitoring of environmental conduct of abroad banks should be conducted.

\subsection{Green Banking in Oman}

In Oman, Miah and Rahman (2017) found that provision of environmental effect during loan approval are not implemented by the selected banks for green initiatives. The study emphasized that the concept of eco-house can be implemented through financial sector. However, most of the banks required central bank to issue some guideline for the implementation of green activities.

\subsection{Green Banking in United Arab Emirates (UAE) and Jordan}

In a comparative study between UAE and Jordan, Jahamani (2003) found that there is some level of awareness related to environmental issues, but response to environmental preservation is very low. The study also found that there is no difference between UAE and Jordan in term of environmental awareness, involvement, and reporting.

\subsection{Green Banking in Singapore}

In Singapore, Sachs, Woo, Yoshino, and Taghizadeh-Hesary (2019) indicates that current investments in renewable projects have been declining and in future, it can decline more because fossil fuels dominating energy investment. This can be a threat for the acceleration of green energy which is needed to meet the climate, energy, and fresh air goals. They further claim, for achieving sustainable development goals, it is necessary to create opportunities for green projects. There is a need to develop green products and policies such as green bonds, green banks, green fiscal policies, green central banking etc.

\section{Methodology}

\subsection{Data Collection}

The primary data is gathered through emails and telephonic recorded interviewees.

\subsection{Sample and Population}

At present, there are total of 26 banks $^{3}$ in Pakistan. The respondent from all banks are selected for analysis, out of that total of 5 respondent from full-fledged Islamic banks, 14 from traditional banks and 7 Shariah scholar have participated in interviews.

\footnotetext{
35 Full-Fledge Islamic banks and 21 Traditional banks
} 


\subsection{Ethics}

Before conducting the telephonic interviews, written consent through electronic means such as email and on-call has been obtained from all the participants agreeing to record the interviews. All respondent provided a preliminary introduction of the research and its objectives in advance. Furthermore, all the participants who are agreed to record and participate in the interviews assured that their anonymity has to be maintained.

\section{Result and Analysis}

\subsection{Challenges and Issues in Green Products in Traditional Banks}

The interviewees have opined regarding the issues and challenges of green products related to different phases from the development to the launching of products. For instance, $29 \%$ of the interviewees from traditional banks were opined, that green product development is not very challenging, however, you need to have good product development consultants, with relevant knowledge and skills. One of them was opined as:

"The green product development officer must be equipped with the knowledge and skills of green banking products and must be aware of customer needs." (Bank 02-T).

When respondents were asked, why knowledge and skills are important for the development of green products, they responded as:

"It is challenging from the product development perspective that if I got to develop the product, then I have to hire engineers to understand all processes and life cycles of these products, all these things, on the bases I will launch that product. I will define the tenor of financing of these products, then viability in term of reciprocity if it is installed, then how cash flows are generating form it, that the customers will pay to me or not. So, it is from both financial as well as the engineering perspective needed a person who can do it all." (Bank 08-T).

Other interviews opined that green product development is not challenging, however, one needs to deal with the challenges after the development of green products, for instance, $29 \%$ of the interviewees from traditional banks opined that one needs to identify the target market, and has to convince the customers for purchasing these products. One interviewee opined in the following way:

“............because you need to convince the customer to purchase the renewable products which cost high” (Bank 01-T).

When interviewees were asked why green products are costly, then most of the interviewees opined that because of lack of international and government level funding these products are costly. One response was worth mentioning.

"In Pakistani environment, you can say it is challenging because green products will be somehow costly. We can understand it with a very simple example, in the UK a person has opened a shoe factory, and he has bound himself that he will not use any material in the making of shoes that can create a negative impact on the environment. He purchased each material from those vendors who have no harmful impact on society, so in this way, his cost becomes so high that he could not bear it because he has no funding for it. Again, if we talk about green businesses or products, then it involved cost, until unless you have international funding, or government level funding. From product structuring and process flow point of view, there are no such challenges. Banks need to target the market and sold the products. Banking products are very standardized, at the broad level we have two products, assets and liabilities, on the assets side, we can provide the loans, and loans are also categorized in term of corporate, SMEs and consumer. On the liabilities side, we have two products 
that are saving and current accounts. So, these are a very standardized product, and the bank needs to identify the target market and make a product for them" (Bank 11-T).

$15 \%$ of the interviewees opined that cost and convincing the customers to purchase green products are other issues in the green products, one interviewee was responded in this way:

"We have launched some small projects, but the same thing if there will be an incentive then it will work. The incentive will be of two types, in the form of an existing market or a regulatory push, such as exemptions and rebates, or the form of a created market demand, then everyone will run after that. So, in both cases, we are not seeing anything like this" (Bank 03-T).

Table 4.1 Summary of the Issues Related to the Green Product Development

\begin{tabular}{|l|l|l|l|}
\hline & & \multicolumn{1}{|c|}{ Reasons } & \multicolumn{1}{|c|}{ After-effects } \\
\hline 1 & Skills and knowledge & Education system & $\begin{array}{l}\text { Lack of good product } \\
\text { development } \\
\text { convincing the management }\end{array}$ \\
\hline 2 & $\begin{array}{l}\text { Identifying the target } \\
\text { market }\end{array}$ & Less user or niche market & $\begin{array}{l}\text { Low penetrations, limited product } \\
\text { line }\end{array}$ \\
\hline 3 & Convincing the customers & Involvement of higher cost, & $\begin{array}{l}\text { Need of higher support from } \\
\text { government and international } \\
\text { funding agencies, need to launch } \\
\text { separate advertisement campaign } \\
\text { and special training of sales staff }\end{array}$ \\
\hline
\end{tabular}

\subsection{Islamic Banks}

$60 \%$ of the interviewees from Islamic banks opined that convincing the customers is the main issue in green products, and $20 \%$ of the interviewees opined that lack of knowledge and skills and lack of incentives are the other two main issues in green product development. One of the respondents summarizes the issues and consequences as:

"Customization is challenging because we need to start a separate advertisement campaign. To sell out these kinds of products you need to specially train the sales staff. You have seen in Pakistan; manufacturer of cars and house finance market of Pakistan is very established. The players who are sitting in these markets their reputation is good. In these scenarios, products flourished. First, for the renewable products, or green banking product, the market is niche. Secondly, there is no mass population for these products. The vendors producing these products are also short, and not too much, and when market competition increased, the prices go down. Because there is no competition, so, no prices discount or leverage available, the prices are such where customers become reluctant to buy" (Bank 17-I).

\subsection{Shariah Scholars}

$57 \%$ of the interviewees from Islamic banking operations opined that convincing the customers is the main issue in green products. While $43 \%$ of the interviewees associated the lack of knowledge and skills as an obstacle for green products and $14 \%$ of the interviewees opined that lack of incentives is the main issues in green product development.

Apart from the similar comments as of traditional and Islamic banks on convincing the customers, lack of knowledge, skills and incentives, Shariah scholars have added some important shariah related issues, such as the validity of contract and selection of the appropriate mode of financing. Two interviewees' opinions were worth noticing.

"So, from this perspective, what will be the products. Which modes of finance will be utilized here? You can take the example of microfinance banking there is no roll of banks in it. Similarly, there is an organization, FINCA. It is working in Pakistan as well and many Arab countries. Basically, it is an 
American firm and doing Islamic banking there, and not in Pakistan, why? because with reference to Islamic banking there is no framework in Pakistan for microfinance which can lead it. In this, there is a role of the regulator, when these things will come till now no product development from this perspective" (SSTB-20).

“....... because in product development there comes online products, e-commerce products, fintech, digitalization, mobile banking and blockchain etc. because they want a peer to peer, in all these keeping in mind the Shariah requirement, is still a challenge. Much work is needed on it and people are already researching it, whether they are Shariah compliant or not, and as you know that on blockchain and krypton currency also research is going. Similarly, as I told in online products there is a challenge of offer and acceptance and validity of contract. So, fulfilling all these shariah requirement, it is a challenge" (SSTB-22).

Table 4.2 Summary of the Issues Related to the Green Product Development

\begin{tabular}{|l|l|l|l|}
\hline 1 & Skills and knowledge & $\begin{array}{l}\text { Lack of awareness, involvement of } \\
\text { technology, to fulfill Shariah } \\
\text { requirements as well, lack of research } \\
\text { and development. }\end{array}$ & $\begin{array}{l}\text { When we go to the grass-root } \\
\text { level or lower level and work in } \\
\text { all areas, then all these issues will } \\
\text { come with more intensity. No } \\
\text { framework, meeting the } \\
\text { requirements of Shariah, no } \\
\text { research and development. }\end{array}$ \\
\hline 2 & $\begin{array}{l}\text { Identifying the target } \\
\text { market with appropriate } \\
\text { mode of finance }\end{array}$ & $\begin{array}{l}\text { Less users, niche market, lack of } \\
\text { venture capital }\end{array}$ & $\begin{array}{l}\text { Limiting the } \\
\text { opportunities, need to upgrade } \\
\text { marketing skills or way of dealing, } \\
\text { need to train sales team. }\end{array}$ \\
\hline 3 & $\begin{array}{l}\text { Convincing the customers } \\
\text { Heavy capital requirements }\end{array}$ \\
\hline
\end{tabular}

\section{Summary, Conclusion and Recommendations}

The objective of the study was to find the issues and challenges in green product development in Islamic and traditional banks of Pakistan. To achieve the objective primary data collection methodology was adopted. Data was collected through in-depth semi-structured interviewee technique. The interviewees of the study were green banking officers and shariah scholars of traditional and Islamic banks of Pakistan. Interviews are conducted through telephonic recorded calls and emails. Total of 26 interviews were conducted. The results indicate that lack of skills, knowledge, identification of the target market with the appropriate mode of financing and convincing the people are some main obstacles in green banking product formulation and implementation.

Recommendations for the improvement of green banking have been collected from 14 respondents of traditional banks, 5 respondents of Islamic banks and 7 respondents of Islamic banking operation of traditional banks.

- It is also a well-known fact that assigning targets guided to move in the right direction, keeping this fact in mind some interviewees also insisted that instead of looking on banks for taking some initiatives, SBP needs to assigning product development targets to banks.

- Besides penalties, there should be a reward mechanism. Though, the interviewees consider that only recognition may not be sufficient at this time to encourage banks to adopt green banking, there must be some benefit such as relief in tax, rebates or leverages in the existing products. SBP should lessen the documentations or loosening the requirements for banks so they can easily process the loans then eventually banks' cost will be reduced, and they can pass on these things. 
- Incentives should be offered to the industries to adopt green initiatives and reducing environmental impact. There should be some incentive from the policymakers, such as rebates or leverages in the existing products. If such incentives will be there, then green banking will take some shape or structure. Apart from incentives, there should be some demand for green banking products. The interviewees also opined that in the absence of demand, green banking may only include some more check on customers, and may cause inconvenient. Therefore, the creation of demand is necessary for the promotion of green banking products. Policymakers need to push the industry by giving them incentives or provide more incentives to banks. Further, policymakers need to provide some incentives to those who are qualifying the definition of green. There should be ranking or competition of banks so that healthy competition can be created.

- The development of courses related to green banking can overcome the issue of lacking skills and competences for the future. This study indicates that professionals with only one-sided knowledge are gradually taking place in the banks as green banking offices. Therefore, some provisions must be there for newly hired green banking officers to be qualified by asking them to complete some scholastic requirements, for example, attending a green banking certified course. However, regulators, government and professional organizations should take part in support of such requirements. For example, entrepreneurs, academics and professionals should form a network to identify the needs and design such courses and build the infrastructure to produce qualified green banking officer. Although the interviewees opined that there is lack of adequate infrastructure in the country to support green banking, it seems that the issue is with lack of awareness, organization and a lack of training. The universities of Pakistan must be well prepared to support training programs and must have some specialized training institutes, on the other side there must be some role of entrepreneurs to provide training to fill the skills gap.

- The board should annually assess the qualification of green banking officer to determine whether the knowledge and experience of the green banking officer fulfil the strategic demands of the bank. These assessments must be considered while hiring new green banking officers or delegating the responsibilities to the existing employees.

- In order to address the issue of lack of training, there must be some training related provision. Apart from the current provisions related to training, the interviewees recommended that there must be some more clauses to ensure that senior and middle-level managers can get training regularly. Banks still would have more knowledge into they need to be more upgrade about the latest happenings in the world. Considering the lack of time for employees, the provision must be flexible to allow a reasonable time for employees to update with these requirements.

- There is a need for the continuous support of the government, regulators, banks, peoples and educational institutions researcher. If everybody starts talking about something, they will provide push and eventually, an environment will be developed. Therefore, policymaker will continuously strive for the betterment in their policies and should have focused on green banking.

\section{References}

Aizawa, M., \& Yang, C. (2010). Green Credit, Green Stimulus, Green Revolution? China's Mobilization of Banks for Environmental Cleanup. The Journal of Environment \& Development, 19(2), 119-144.

Alam, K. T., Julker, N. M., Rashedul, I., \& Khadiza, B. (2017). green banking: Bangladesh Perspective and International Experiences. Russian Journal of Agricultural and Socio-Economic Sciences, 1(61), 10-16.

Bal, Y., Faure, M., \& Liu, J. (2014). The Role of China's Banking Sector in Providing Green Finance. Duke Environmental Law \& Policy Forum, 24, 89-140.

Bhardwaj, B. R., \& Malhotra, A. (2013). green banking Strategies: Sustainability Through Corporate Entrepreneurship. Greener Journal of Business and Management Studies, 3(4), 180-193.

Biswas, N. (2011). Sustainable green banking Approach: The Need of the Hour. Business Spectrum, 1(1), 32-38. 
Chen, Z., Hossen, M. M., Muzafary, S. S., \& Begum, M. (2018). green banking for Environmental SustainabilityPresent Status and Future Agenda: Experience from Bangladesh. Asian Economic and Financial Review, 8(5), 571-585.

Chowdhury, A., \& Dey, M. (2016). green banking Practices in Bangladesh. The Cost and Management, 44(2), 34-39.

Cui, Y., Geobey, S., Weber, O., \& Lin, H. (2018). The Impact of Green Lending on Credit Risk in China.

Sustainability, 10(6), 1-16.

Deka, G. (2015). green banking Practices: A Study on Environmental Strategies of Banks with Special Reference to State Bank of India. Indian Journal of Commerce and Management Studies, 6(3), 11-19.

Fayez, A., Mohammad, Z. N., \& Md, H. (2013). Factors Behind the Adoption of green banking by Bangladeshi Commercial Banks. ASA University Review, 7(2).

Ghosh, S. K., Ghosh, P. K., \& Chowdhury, S. (2018). Essential of Central Bank's Regulatory Policy to Strengthen green banking Practice and Reporting in a Country. Asian Journal of Finance \& Accounting, 10(2), 133-150.

Hayder, M. (2012). green banking and its Practices in Bangladesh. Term Paper, Department of Finance and Banking, University of Chittagong, 16-35.

Hoshen, M. S., Hasan, M. N., Hossain, S., Al Mamun, M. A., \& Mannan, A. (2017). Green Financing: An Emerging Form of Sustainable Development in Bangladesh. IOSR Journal of Business and Management, 19(12), 24-30.

Hossain, D. M., Bir, A., Tarique, K. M., \& Momen, A. (2016). Disclosure of green banking Issues in the Annual Reports: A Study on Bangladeshi Banks. Middle East J. Bus, 7, 19-30.

Islam, M. S., \& Das, P. C. (2013). green banking Practices in Bangladesh. IOSR Journal of Business and Management, 8(3), 39-44.

Jahamani, Y. F. (2003). Green Accounting in Developing Countries: The Case of UAE and Jordan. Managerial Finance, 29(8), 37-45.

Julia, T., Rahman, M. P., \& Kassim, S. (2016). Shariah Compliance of green banking Policy in Bangladesh. Humanomics, 32(4), 390-404.

Lalon, R. M. (2015). green banking: Going green. International Journal of Economics, Finance and Management Sciences, 3(1), 34-42.

Masukujjaman, M., \& Aktar, S. (2013). green banking in Bangladesh: A Commitment Towards the Global Initiatives. Journal of Business and Technology (Dhaka), 8(1-2), 17-40.

Masukujjaman, M., Siwar, C., Mahmud, M. R., \& Alam, S. S. (2015). Banker's Perception on green banking-An Empirical Study On Islamic Banks In Bangladesh. Management \& Marketing Journal, 13(2).

Miah, D. M., \& Rahman, S. M. (2017). green banking: The Case of Commercial Banking Sector in Oman. Paper presented at the The Islamic Economic System Conference (Lecons 2017).

Millat, K. M., Chowdhury, R., \& Singha, E. A. (2013). green banking in Bangladesh: Fostering Environmentally Sustainable Inclusive Growth Process. Bangladesh: Department of Communications and Publications, Bangladesh Bank.

Nath, V., Nayak, N., \& Goel, A. (2014). green banking Practices-A Review. IMPACT: International Journal of Research in Business Management (IMPACT: IJRBM), 2, 45-62.

Sachs, J., Woo, W. T., Yoshino, N., \& Taghizadeh-Hesary, F. (2019). Handbook of Green Finance: Energy Security and Sustainable Development (1st ed.). Singapore: Springer

Sahoo, P., \& Nayak, B. P. (2007). green banking in India. The Indian Economic Journal, 55(3), 82-98.

Sekreter, A. (2017). Green Finance and Islamic Finance. International Journal of Social Sciences \& Educational Studies, 4(3), 115-121.

Shetty, S., \& Unnikrishnan, G. (2017). A Comparative Study of green banking Practices in India \& Usa. International Journal of Research in Finance and Marketing (IJRFM), 7(1), 10-19.

Thombre, K. A. (2011). The New Face of Banking: green banking. Research Paper-Commerce, 1(2), 1-4.

Verma, M. K. (2012). green banking: A Unique Corporate Social Responsibility of India Banks. International Journal of Research in Commerce \& Management, 3(1), 110-114.

Zhang, B., Yang, Y., \& Bi, J. (2011). Tracking the Implementation of Green Credit Policy in China: Top-Down Perspective and Bottom-Up Reform. Journal Of Environmental Management, 92(4), 1321-1327. 